\title{
PELATIHAN PENGELOLAAN PERPUSTAKAAN (OTOMASI PERPUSTAKAAN) DI SDN 1 WAMEO KECAMATAN BATUPOARO KOTA BAUBAU
}

\author{
Azaz Akbar¹, S. Hafidhawati Andarias'2, Wa Ode Husnia ${ }^{3}$ \\ ${ }^{1}$ Program Studi Pendidikan Guru Sekolah Dasa, Fakultas Keguruan dan Ilmu Pendidikan dan \\ Universitas Muhammadiyah Buton \\ ${ }^{2}$ Program Studi Pendidikan Biologi, Fakultas Keguruan dan Ilmu Pendidikan dan Universitas \\ Muhammadiyah Buton \\ ${ }^{3}$ Program Studi Bimbingan Konseling, Fakultas Keguruan dan Ilmu Pendidikan dan \\ Universitas Muhammadiyah Buton \\ e-mail: azaz.akbar23@gmail.com
}

\begin{abstract}
Abstrak
Ketersediaan Senayan Library Management System (SLiMS) sebagai aplikasi Free Open Source Software (FOSS) belum diketahui oleh pengelolah Perpustakaan sekolah pada umumnya. SDN 1 Wameo sebagai penyelenggara pendidikan sekolah dasar di Kota Baubau contohnya belum mengetahui pemanfaatan software yang dimaksud. Keadaan ini terbukti dengan ketersediaan komputer perpustakaan sekolah yang masih belum difungsikan sebagai perangkat utama dalam pengadministrasian perpustakaan sekolah. Kendala ini terjadi karena pengelola perpustakaan tidak mendapatkan akses informasi yang bisa dijadikan rujukan dalam pelaksanaan pengelolaan perpustakaan yang ideal. Hasil dan luaran dari PKM ini adalah peningkatan pemahaman dan keterampilan dari pengelolah Perpustakaan Sekolah SDN 1 Wameo berbasis (SLiMS). Diharapkan juga terwujud sistem administrasi sekolah yang sesuai Standar Operasional Prosedur (SOP) yang bermuara sebagai sekolah dasar yang menjadi panduan sekolah lain dalam sistem pengelolaan perpustakaan yang terotomasi. Pada pelaksanaan program kemitraan masyarakat ini, Tim pengabdi menyediakan aplikasi (FOSS) berupa SliMS kepada pihak sekolah, melakukan pengenalan dan pelatihan penggunaan (SLiMS) kepada pengelolah perpustakaan, serta melakukan pendampingan penerapan (SLiMS) dan evaluasi.
\end{abstract}

Kata Kunci: Software Perpustakaan, Slims, FOSS

\section{A. Pendahuluan}

SliMS adalah perangkat lunak sistem manajemen perpustaakaan (Library management system) yang bersifat terbuka bagi siapapun, dan juga memiliki sumber terbuka yang dilisensikan di bawah GPL v3. Aplikasi ini pertamakali dikembangkan dan digunakan oleh Perpustakaan Kementerian Pendidikan Nasional, Pusat Informasi dan Hubungan Masyarakat, Kementerian Pendidikan Nasional. 
Aplikasi SliMS dibangun dengan menggunakan PHP, basis data MySQL, dan pengontrol versi Git. Pada tahun 2009, SliMS mendapat penghargaan tingkat pertama dalam ajang INAICTA 2009 untuk kategori open source. SENAYAN adalah open source software (OSS) berbasis web untuk memenuhi kebutuhan automasi perpustakaan (library automation) skala kecil hingga skala besar. Dengan fitur yang cukup lengkap dan masih terus aktif dikembangkan, SENAYAN sangat cocok digunakan bagi perpustakaan yang memiliki koleksi, anggota dan staf banyak dilingkungan jaringan, baik itu jaringan lokal (intranet) maupun internet.

Keunggulan SENAYAN lainya adalah multi-platform, yang artinya bisa berjalan secara native hampir disemua sistemoperasi yang bisa menjalankan bahasa pemrograman PHP dan RDBMS MySQL (http://www.mysql.com). SENAYAN sendiri dikembangkan di atas platform GNU/Linux dan brjalan dengan baik di atas platform lainya seperti Unix*BSD dan Windows. SENAYAN merupakan aplikasi berbasis web dengan pertimbangan crossplatform. Sepenuhnya dikembangkan menggunakan software open source yaitu : PHP Web Scripting Language, (www.php.net) dan MySQL database server (www.mysql.com). Untuk meningkatkan interaktifitas agar bisa tampil seperti aplikasi deskop, juga digunakan teknologi AJAX (Asynchronous JavaScript and XML).

Senayan juga menggunakan Software Open Source untuk menambah fitur seperti $\mathrm{Ph}$-pThumb dan simbio (development platform yang dikembangkan dari proyek igloo). Untuk itu, senayan dilisensikan dibawah GPL3 yang menjamin kebebasan dalam mendapatkan, memodifikasi dan mendistribusikan kembali. Lebih detail tentang GPLv3 bisa dibaca di http://www.gnu.org/licenses/gpl-3.0.html.

Pada perkembangan awalnya, senayan versi 1 dan 2 tidak dirilis ke publik kartena masih tahap uji coba dan sedang dalam penyempurnaan. Sejak versi 3, senayan dianggap sudah stabil untuk dirilis kepublik dan sudah waktunya di uji coba oleh komunitas pustakawan. Diharapkan dengan per-to-peer review oleh publik, software senayan semakin stabil dan fitur-fiturnya bisa semakin beragam dan mampu mengakomodasi banyak kebutuhan. Untuk melihat demo dan download software Senayan, bisa berkunjung ke http://senayan.diknas.go.id.

Idealnya, setiap pustakawan memanfaatkan kecanggihan teknologi informasi untuk mendukung pengelolaan perpustakaan. Salah satu contoh konkritnya yaitu perpustakaan menggunakan Aplikasi yang disebut dengan Senayan Library Management System atau 
SliMS. Peluang ini tampaknya belum bisa dimanfaatkan oleh beberapa perpustakaan sekolah di Kota Baubau. Terbukti dengan masih ditemukanya perpustakaan sekolah yang belum memanfaatkan Senayan Library Management System atau SliMS ataupun software yang sejenis.

Pentingnya pemahaman untuk memanfaatkan Free Open Source Software (FOSS) berupa Senayan Library Management System atau SliMS menjadi keharusan bagi setiap pengelolah perpustakaan. Banyaknya penjual software gelap menyebabkan darurat yang perlu diantisipasi lebih awal.

\section{B. Masalah}

Berdasarkan hal tersebut, maka yang menjadi masalah dalam pengabdian ini adalah:

1. Pengelola perpustakaan yang belum mengenal Free Open Source Software (FOSS) berupa Senayan Library Management System yang sebenarnya dapat diperoleh secara gratis.

2. Pengelolaan perpustakaan yang konvensional mempersulit siswa dalam menelusur informasi.

\section{Metode Pelaksanaan}

Metode yang digunakan dalam kegiatan Pengabdian Kepada Masyarakat (PPM) adalah melalui ceramah, diskusi dengan mengidentifikasi kasus per kasus, pemecahan kasus dan demonstrasi (penerapan langsung di ruangan) dan simulasi (Hardin, 2019: 32). Kegiatan Pengabdian ini dilakukan selama delapan bulan yang terdiri dari tiga tahapan: (1) Tahap Perencanaan, (2) Tahap Pelaksanaan, dan (3) Tahap Evaluasi.

1. Tahap Perencanaan telah ditetapkan hal-hal sebagai berikut:

a) Melakukan pendekatan kepada pemangku kepentingan setempat untuk memulai menawarkan solusi dari permasalahan yang ada. Pendekatan dilakukan kepada Kepala Sekolah SDN 1 Wameo dan SDN 2 Wameo.

b) Bersama dengan pemangku kepentingan membuat persetujuan program dan kesepakatan untuk dukungan kegiatan.

c) Menyiapkan materi-materi dan prosedur yang akan digunakan untuk penyampaian materi terkait dengan pemanfaatan Free Open Source Software (FOSS) berupa Senayan Library Management System atau SliMS. 
d) Memberikan penjelasan dan uraian tugas pengelolah perpustakaan sekolah, serta fungsi dari keberadaan perpustakaan sekolah.

e) Menyusun jadwal kegiatan pelatihan yang akan diberikan kepada pengelolah Perpustakaan Sekolah Dasar Negeri 1 Wameo.

2. Tahap Pelaksanaan Kegiatan.

a) Menyediakan aplikasi Free Open Source Software (FOSS) berupa Senayan Library Management System atau SliMS kepada pihak sekolah.

b) Memberikan penyuluhan/penyampaian materi tentang Senayan Library Management System atau SliMS kepada pengelolah Perpustakaan Sekolah Dasar Negeri 1 Wameo.

c) Memberikan workshop, praktik, dan simulasi penggunaan Senayan Library Management System atau SliMS kepada pengelolah Perpustakaan Sekolah Dasar Negeri 1 Wameo.

d) Berkordinasi dengan perpustakaan daerah untuk memberikan kontribusi terkait pengembangan layanan pada Perpustakaan Sekolah Dasar Negeri 1.

3. Tahap Evaluasi terdiri atas:

a) Melakukan evaluasi terhadap kemampuan kognitif pengelola perpustakaan terkait dengan penggunaan Free Open Source Software (FOSS) berupa Senayan Library Management System atau SliMS.

b) Melakukan evaluasi terhadap kemampuan afektif/sikap pengelolah perpustakaan sekolah pengelolaan perpustakaan yang profesional.

c) Melakukan evaluasi terhadap kemampuan praktik/psikomotor terhadap pengelolaan perpustakaan sekolah.

d) Melakukan evaluasi tindak lanjut kerjasama antar perpustakaan sekolah yang dilakukan.

Tabel 1. Jadwal Kegiatan

\begin{tabular}{|c|c|c|c|c|c|c|c|c|c|c|c|c|c|}
\hline \multirow{2}{*}{ No } & \multirow{2}{*}{ Nama Kegiatan } & \multicolumn{12}{|c|}{ Bulan } \\
\hline & & 1 & 2 & 3 & 4 & 5 & 6 & 7 & 8 & 9 & & & 12 \\
\hline 1 & $\begin{array}{l}\text { Persiapan rapat koordinasi dengan pihak } \\
\text { sekolah }\end{array}$ & & & & & & & & & & & & \\
\hline 2 & Program Pelatihan & & & & & & & & & & & & \\
\hline 3 & Pelaksanaan Pengabdian & & & & & & & & & & & & \\
\hline 4 & Evaluasi & & & & & & & & & & & & \\
\hline 5 & Laporan Akhir & & & & & & & & & & & & \\
\hline 6 & Publikasi & & & & & & & & & & & & \\
\hline
\end{tabular}




\section{Pembahasan}

Keterampilan pengelolah perpustakaan memberikan pengaruh yang positif terhadap perkembangan budaya baca siswa. Pada konteks yang terjadi, pengelolaan perpustakaan yang asal-asalan masih menjadi pemandangan umum untuk disaksikan. Padahal minat dan ketertarikan siswa untuk berkunjung keperpustakaan salah satunya dipengaruhi pengelolaan yang baik. Hal tersebut diperburuk dengan sebuah pandangan pengelolah perpustakaan yang masih menganggap dirinya sebagai penunggu buku, bukan sebagai garda ilmu pengetahuan.

Pelaksanaan kegiatan PKM ini akan memberikan pengetahuan dan keterampilan bagi SDN 1 Wameo, sehingga mereka memiliki keterampilan dalam mengelolah perpustakan sekolah berbasis Senayan Library Management System (SLiMS) dan sistem pengadministrasian sekolah berdasarkan Standar Operasional Prosedur (SOP). Harapan dengan pelaksanaan PKM ini menjadikan sekolah SDN 1 Wameo menjadi salah satu pusat percontohan oleh sekolah lain yang ada di Kota Baubau dan sekitarnya, terkhusus pada bidang perpustakaan.

Persoalan yang dihadapi oleh mitra ini adalah kurangnya pemahaman tenaga pengelolah perpustakaan untuk memanfaatkan aplikasi SliMS sebagai sistem yang mempermudah dalam pengelolaan perpustakaan. Pengelolaan perpustakaan yang masih asalasalan masih terjadi pada mitra. Kurangnya pemahaman pengelolah perpustakaan bisa membuka ruang kepada para pencari proyek yang tidak bertanggung jawab, misalnya dengan menjual software yang sebenarnya bisa diperoleh secara gratis melalui play store.

Oleh karena itu, dalam rangka membantu memecahkan persoalan mitra tersebut, maka diperkenalkan aplikasi berupa Senayan Librarai Management Sistem (SLiMS) untuk memudahkan pengelolaan perpustakaan, baik dalam pengklasifikasian koleksi, pengkatalogan, sampai pada pelayanan pada pengguna (pemustaka).

Perkembangan perpustakaan berbasis teknologi informasi bagi pengelola perpustakaan dapat membantu pekerjaan di perpustakaan melalui fungsi otomasi perpustakaan, sehingga proses pengelolaan perpustakaan lebih efektif dan efisien. Fungsi otomasi perpustakaan menitikberatkan pada bagaimana mengontrol sistem administrasi layanan secara otomatis terkomputerisasi. Sedangkan bagi pengguna dapat membantu mencari sumber informasi yang diinginkan dengan menggunakan catalog online yang dapat 
diakses melalui internet, sehingga pencarian informasi dapat dilakukan kapan dan dimanapun ia berada.

Pentingnya pemahaman untuk memanfaatkan Free Open Source Software (FOSS) berupa Senayan Library Management System atau SliMS menjadi keharusan bagi setiap pengelolah perpustakaan. Banyaknya penjual software gelap menyebabkan darurat yang perlu diantisipasi lebih awal.

Berdasarkan permasalahan tersebut, program iptek bagi masyarakat yang dilakukan untuk mengatasi masalah yang akan diharadapi pihak sekolah, dibagi menjadi beberapa tahap:

1. Menyediakan aplikasi Free Open Source Software (FOSS) berupa Senayan Library Management System atau SliMS kepada pihak sekolah.

2. Pengenalan dan pelatihan penggunaan Senayan Library Management System (SLiMS).

3. Pendampingan penerapan Senayan Library Management System (SLiMS) dan pengelolaan sekolah berdasarkan Standar Operasional Prosedur (SOP).

4. Pendampingan penggunaan Senayan Library Management System (SLiMS).

Secara rinci solusi dari masing-masing bidang yang akan diselseaikan persoalanya adalah sebagai berikut: Menawarkan solusi untuk memberikan pemahaman berupa pelatihan terkait pengelolaan perpustakaan dengan memanfaatkan Free Open Source Software (FOSS) berupa Senayan Library Management System atau SliMS sehingga bisa terwujud perpustakaan sekolah yang tersistem dan terotomasi.

Berikut fitur-fitur serta gambar yang dapat diakses dengan menggunakan SliMS adalah sebagai berikut:

1. Menambahkan daftar bahan pustaka baru dalam komputer

a. Pilih menu Bibliography yang tertera pada menu utama 


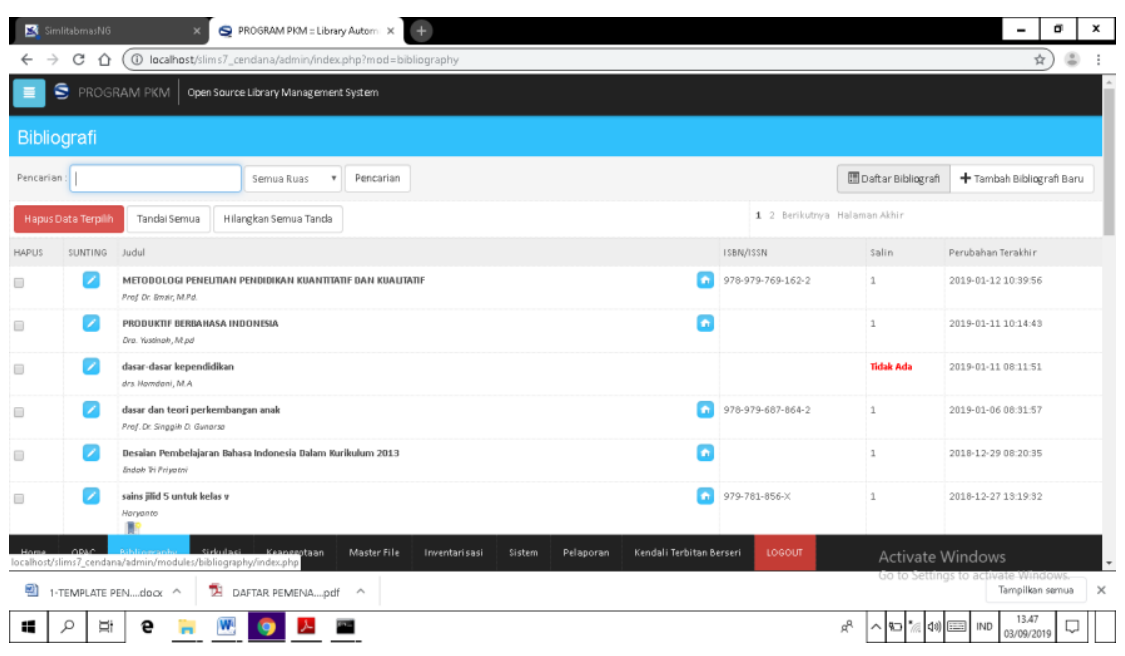

b. Klik pilihan tambah bibliografi baru

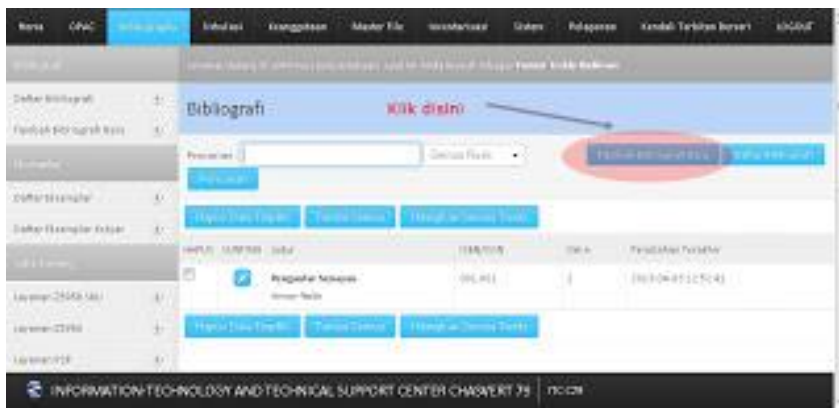

c. Isikan data-data mengenai bahan pustaka yang akan ditambahkan pada kolom yang telah tersedia

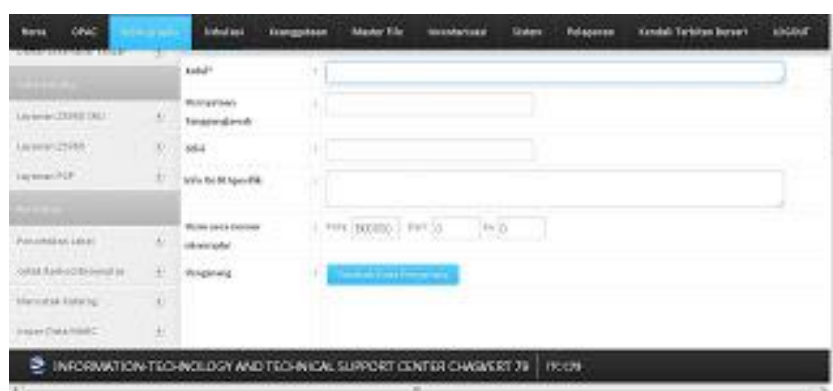

2. Mencetak Label buku 


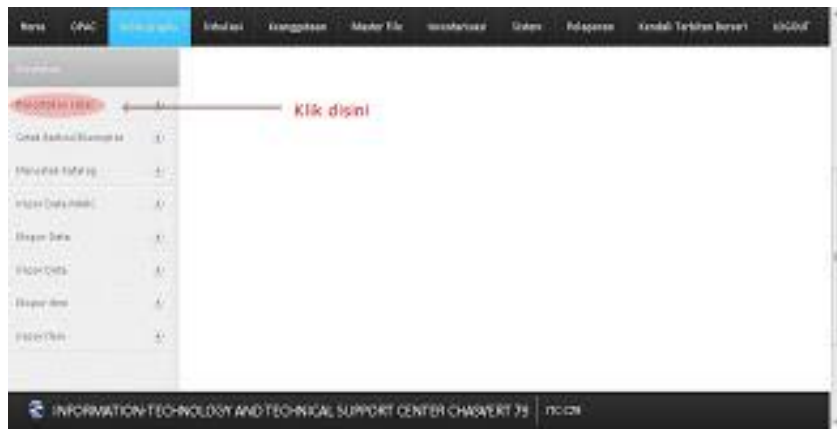

3. Mencetak Barcode

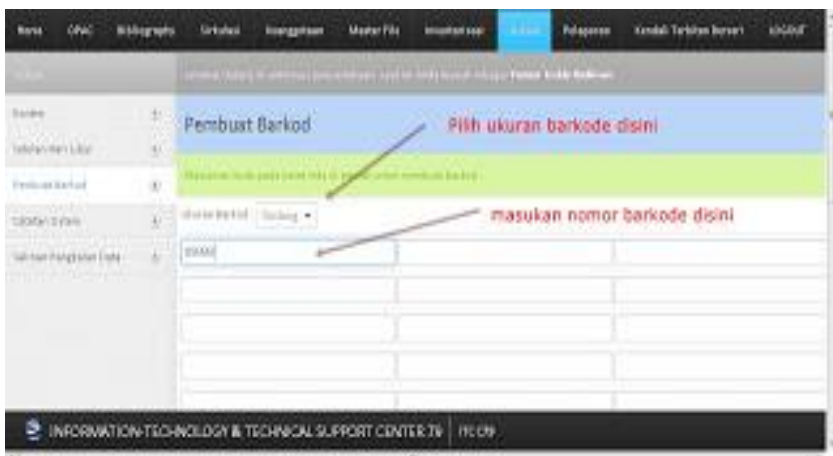

4. Pembuatan Katalog

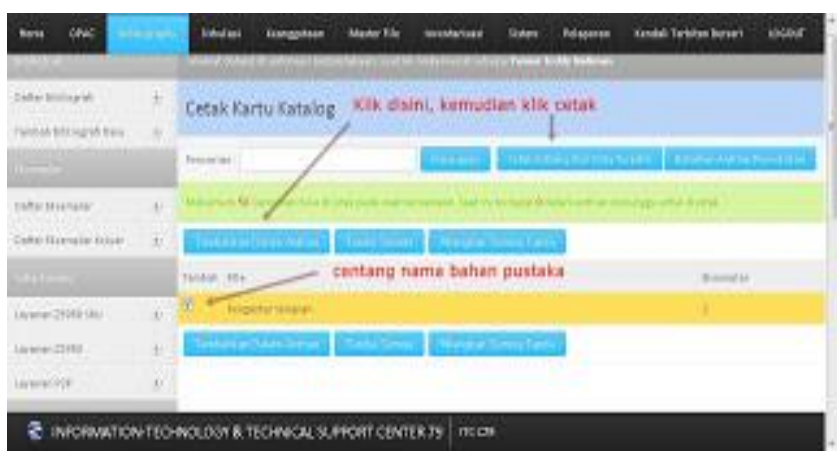

5. Pelayanan Bahan Pustaka

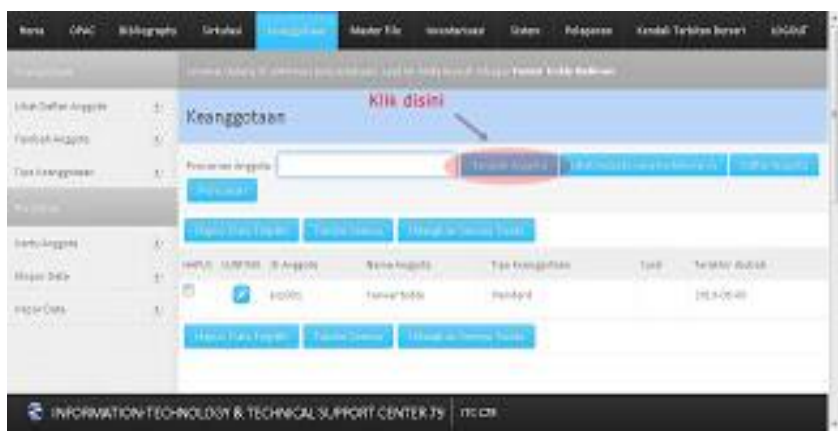


Vol.4 No. 1 April 2020

6. Layanan Sirkulasi dan Reservasi

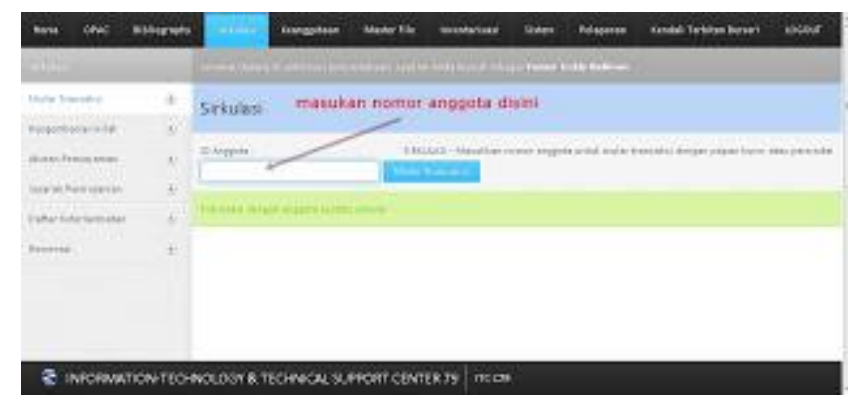

7. Laporan-laporan

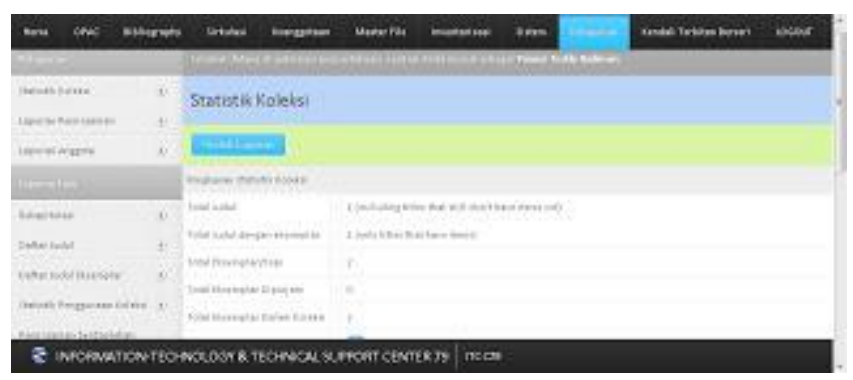

\section{E. Kesimpulan}

Berdasarkan permasalahan dan pembahasan tersebut, maka guru yang mengikuti pelatihan tersebut mengetahui keadaan dan pemanfaatan Free Open Source Software (FOSS) berupa Senayan Library Management System yang diperoleh secara gratis. Dengan pengabdian ini juga, pengelola perpustakaan SDN Wameo mulai membenah perpustakaanya dari yang bersifat konvensional menuju pada perpustakaan yang terotomasi.

\section{DAFTAR PUSTAKA}

Akbar, Azaz, (2018). Pengelolaan Perpustakaan Perbasis Akreditasi. Makassar: Leisyah.

Atjtje, Syarifuddin. (2006). Manajemen Layanan Prima Perpustakaan. Makasar: Grow Centre PTS Kopertis Wilayah IX.

Hardin. (2019). Pembinaan Pengurus Persaudaraan Beladiri Kempo Indonesia (Perkemi) Dojo Sorawolio Dalam Melaksanakan Peran dan Fungsi Manajemen Organisasi. Jurnal Pengabdian Kepada Masyarakat MEMBANGUN NEGERI Vol. 3 No.1 April 2019.

HS. Lasa. (2009). Manajemen Perpustakaan Sekolah. Yogyakarta: Pinus.

HS. Lasa. (2016). Manajemen Perpustakaan Sekolah/ Madrasah. Yogyakarta: Ombak. 
HS. Lasa. (2017). Manajemen Sumber Daya Manusia Perpustakaan. Yogyakarta: Ombak

Flandi, Tjiptono, Georgius \& Chandra. (2005). Service Quality Statisfaction. Yogyakarta: Andi Offset.

Furqon. (2004). Statistik Terapan Untuk Pengabdian. Bandung: Alfabeta.

Hermawan, Rahman dan Zulfikar. (2006). Etika Kepustakawan Suatu Pendekatan Terhadap Kode Etik Pustakawan Indonesia. Jakarta: Sagung Seto. 